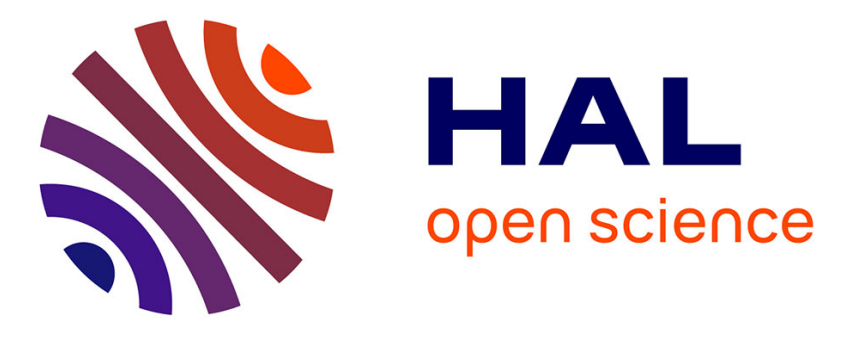

\title{
Induced abortions and teenage births among asylum seekers in the Netherlands: analysis of national surveillance data
}

Simone Goosen, Daan Uitenbroek, Cecile Wijsen, Karien Stronks

\section{- To cite this version:}

Simone Goosen, Daan Uitenbroek, Cecile Wijsen, Karien Stronks. Induced abortions and teenage births among asylum seekers in the Netherlands: analysis of national surveillance data. Journal of Epidemiology and Community Health, 2009, 63 (7), pp.528-n/a. 10.1136/jech.2008.079368 . hal00477866

\section{HAL Id: hal-00477866 https://hal.science/hal-00477866}

Submitted on 30 Apr 2010

HAL is a multi-disciplinary open access archive for the deposit and dissemination of scientific research documents, whether they are published or not. The documents may come from teaching and research institutions in France or abroad, or from public or private research centers.
L'archive ouverte pluridisciplinaire HAL, est destinée au dépôt et à la diffusion de documents scientifiques de niveau recherche, publiés ou non, émanant des établissements d'enseignement et de recherche français ou étrangers, des laboratoires publics ou privés. 


\section{Induced abortions and teenage births among asylum seekers in the Netherlands: analysis of national surveillance data}

Simone Goosen,(1, 2) Daan Uitenbroek,(3) Cecile Wijsen,(4) Karien Stronks(2)

1 Department of Community Health Services for Asylum Seekers, Netherlands Association for Community Health Services, PO Box 85300, 3508 AH Utrecht, the Netherlands

2 Department of Social Medicine, Academic Medical Center-University of Amsterdam, Amsterdam, The Netherlands

3 Quantitative Skills, Consultancy for Research and Statistics, Hilversum, The Netherlands

4 Rutgers Nisso Groep - Dutch Expert Centre on Sexuality, Utrecht, The Netherlands

Correspondence to:

S Goosen

e-mail: $\quad$ sgoosen@ggd.nI

telephone: $\quad+31302525088$

fax: $\quad+31302511869$

Keywords: Reproductive health, Refugees, Asylum seekers, Abortion (induced), Teenage pregnancy

Word count: 2995 


\section{ABSTRACT}

Background Asylum seekers are assumed to be a vulnerable group with respect to sexual and reproductive health. The objective of this study is to quantify induced abortion and teenage birth indicators for asylum seekers.

Methods The population includes all female asylum seekers aged 15-49 in the Netherlands between September 2004 and August 2005. Information about induced abortions was collected from notification forms and electronic patient files. The central agency for the reception of asylum seekers provided population and birth data.

Results Among asylum seekers the abortion rate (14.4/1000 women) and teenage birth rate (49.1/1000) were higher than average in the Netherlands (8.6/1000 and 5.8/1000). Great differences were found between subgroups. High abortion rates were seen among women who were pregnant on arrival or got pregnant in the first months after arrival at the reception facilities. Abortion and teenage birth rates were particularly high among asylum seekers aged 15-19 from specific parts of Africa and Asia. Abortion ratios were high among asylum seekers aged 30-49 from parts of Europe and Asia. Decreases in the abortion rate and teenage birth rate were observed as the length of stay increased.

Conclusion Abortions and teenage births were more common among asylum seekers than among the overall population of the Netherlands. The increased rates were a consequence of subgroups being at high risk. Abortion and teenage birth rates were very high among women who were pregnant on arrival or got pregnant in the first few months after arrival, but decreased as length of stay increased. 


\section{INTRODUCTION}

Insight into sexual and reproductive health indicators is considered to be crucial for policy and programmatic decisions concerning reproductive health services.[1-4] Asylum seekers are assumed to be a vulnerable group with respect to sexual and reproductive health.[5-9] By the end of 2004 European countries were host to more than two million refugees and 270000 asylum seekers.[10] About a quarter of the refugees and internally displaced persons worldwide are women of reproductive age.[11] Studies on fertility and contraceptive use in emergency phase camps revealed a mixed response to childbearing among those affected by war.[12] Quantitative data about the sexual and reproductive health status of asylum seekers in industrialised countries are, however, very scarce.[9]

The asylum population is diverse in many factors that are known to be associated with abortions and teenage birth rates, e.g. age, countries of origin, socioeconomic status, and level of education.[13, 14] The sexual and reproductive health of asylum seekers may in addition be influenced by factors such as experiences in the country of origin and during their flight, the uncertainty of the asylum procedure, frequent transfers, absence of social structure, language, and limited knowledge of the health system.[7, 9] We can distinguish between asylum seekers becoming pregnant before or after arrival at the reception facilities. Conception after arrival could have been influenced by the reproductive health services available in the host country. So indicators for this group give a particularly good indication of the groups that need to be targeted with policy and action aimed at preventing unwanted and teenage pregnancies in the host country.

The aim of our study was to estimate the incidence of induced abortions and teenage births in asylum seekers in the Netherlands in 2004-2005. We compared abortion and teenage birth indicators among asylum seekers with indicators for the general population in the Netherlands. In addition, we tried to find out whether the incidence of abortions and teenage births varies between subgroups by age, region of origin, and length of stay in the reception facilities. 


\section{Box 1 Health services for asylum seekers in the Netherlands}

Health services for asylum seekers are very similar to services available to other residents of the Netherlands. A health insurance company, through a special health insurance scheme, has contracted mainstream health care providers to provide these services. Public health services, including sexual and reproductive health promotion, are provided by regional associations of community health services (MOA) in all asylum seekers centres. MOA offers every newly arrived asylum seeker an initial consultation with a practice nurse and, if indicated, a public health doctor. The nurse will in most cases address sexual and reproductive health issues at that occasion as advocated for by Adams et al.[15] MOA nurses are also the first point of contact for asylum seekers for health issues and are responsible for referral to mainstream health care. This includes referring pregnant women to a midwife and helping women to get access to abortion services if they want to terminate an unwanted pregnancy.

Abortion and other sexual and reproductive health services are available free of charge, but asylum seekers aged 21 years and over have to pay for contraceptives themselves. Condoms, though, are available free of charge. 


\section{METHODS}

\section{Data sources}

We assembled data on abortions and live births that took place between 1 September 2004 and 31 August 2005. Nurses from the community health services for asylum seekers (MOA) were requested to report every abortion that came to their knowledge. They did this on a form similar to the Dutch national abortion registry form. In addition, we extracted data from the MOA electronic database for records that contained the International Classification of Primary Care (ICPC) code W83 (induced abortion). We obtained data on live births in the reception facilities from the central agency for the reception of asylum seekers (COA). COA also provided data on the total population in the reception facilities on 1 April 2005 (mid-study), and we used these to estimate the total person years spent in reception facilities during the study period. For comparison with the population of the Netherlands we used data from the Dutch abortion registry[16] and Statistics Netherlands for 2005.[17]

\section{Indicators and demographic variables}

We used the common reproductive health indicators: abortion rate, abortion ratio, and teenage birth rate (box 2).[3] Age at abortion or delivery was calculated using the date of abortion or birth and the woman's own date of birth. Length of stay in the reception facilities at the time of abortion or childbirth was calculated using the date of abortion or delivery and the date of registration at the reception facilities. For the denominator population we used age and length of stay at 1 April 2005. We first grouped the countries of origin according to the regions used by UNHCR.[18] As the numbers were small we merged these into five regions (see footnote table 3 and online table), taking into account geographical location and differences in abortion indicators. Data about the few women from other regions and stateless women are included in all analyses except those by region.

\section{Statistical analysis}

We distinguished three length of stay groups. The first group had a length of stay of less than three months. We chose three months as cut-off point as the pregnancy duration at the time of abortion was less than 13 weeks for more than $95 \%$ of the notified abortions. Women in this group who gave birth or had an abortion were pregnant on arrival. The second group had a length of stay of between three and eight months. Women in this group who gave birth were pregnant on arrival, and women who had an abortion got pregnant after arrival the reception facilities. The third group included women with a length of stay of nine months or longer. All women in this group who gave birth or had an abortion got pregnant after arrival in the reception facilities. Reproductive health choices of this group could have been influenced by services provided in the Netherlands. Women who had an abortion after a length of stay of between three and eight months could also have been influenced in their reproductive health choices by services provided in the Netherlands. These abortions were analysed separately to ensure clarity and consistency in abortion ratio calculations. Because of the limited numbers in the shorter length of stay groups, analysis by age and region of origin was only done for the group with length of stay nine months or longer. 
We performed the analyses using the Statistical Package "R" (http://www.r-project.org) and the online statistical calculator SISA (http://www.quantitativeskills.com/sisa). For the tables we used the Gamma measure as an indicator for ordinal association, chi-square for differences in distribution. The abortion rate is a proportional measure and the proportions were uni-variately compared using the risk ratio and multivariately using Poisson regression. The abortion ratio is in fact a rate ratio. In comparing the different abortion ratios we used a measure which can be interpreted similar to the risk ratio, but we calculated the standard error on the basis of the odds ratio, using the odds of having an abortion against not having an abortion. The standard errors for the ratios were calculated according to the usual methods [19, 20]. For multivariate analysis we used Poisson regression. If the value 1 was not in the confidence interval, we considered the comparison statistically significant. Significant differences are marked bold in the tables.

\section{Box 2 Indicators [3]}

Induced abortion rate: number of abortions per 1000 women aged 15-49 - or per specific subgroup per year.

Induced abortion ratio (to live births): number of abortions per 1000 live births.

Teenage birth rate: number of live births per 1000 women aged 15-19 at delivery per year.

\section{RESULTS}

The overall abortion rate and ratio for asylum seekers were about one and a half times higher (table 1) and the teenage birth rate more than eight times higher than average for the Netherlands (table 2).

\section{Comparison between length of stay groups}

The abortion rates were much higher for women who were pregnant on arrival or got pregnant in the first few months after arrival in the Netherlands than for asylum seekers with length of stay nine months or more (table 1). The abortion ratio for women with length of stay less than three months was lower than for the other groups. We saw the same patterns for the rates and ratios in all age groups (data not shown). We found very high teenage birth rates for girls with length of stay less than three and between three and eight months (table 2). For girls with length of stay nine months or more the birth rate was much lower, but still nearly five times higher than average in the Netherlands (table 2).

\section{Length of stay nine months or more}

The abortion rate and the abortion ratio were strongly associated with age (rate: $t=2.169$; df-t: 1840; $p=0.03$, ratio: $z=-2.093 ; p=0.04$ ) with the highest rate among $15-19$ year olds (table 3 ). Among asylum seekers aged 15-19 and 30-49 the abortion rates were higher than average for the Netherlands in these age groups (table 3 ). The abortion ratio was only half the average for the Netherlands among 15-19 year olds and twice the average for the Netherlands among 30-49 year olds.

The abortion rate differed significantly between regions of origin, even after correction for age differences (dependent variable abortion rate, covariates age group and region of origin entered simultaneously: Chi2=23.6, $\mathrm{df}=4, \mathrm{P}<0.01$ ). The highest rates were found among women from WCS Africa and CES Asia. 
Abortion ratios also differed between regions ( $C h i 2=19.9, \mathrm{df}=4, \mathrm{P}<0.01$ ), but these differences were no longer significant after correction for age (dependent variable abortion ratio, covariates age group and region of origin entered simultaneously: $C h i 2=9.3, d f=4, P=0.05$ ).

Stratified analysis by age and region of origin showed that specific subgroups are at increased risk. In the age group 15-19 the abortion and teenage birth rates for asylum seekers from WCS Africa and CES Asia were significantly very high in comparison with Dutch indicators for this age group (table 3 ).

In the 20-29 age group there were just a slight differences in abortion rates and ratios, and only women from WCS Africa had a significantly higher abortion rate in comparison with the Dutch average. Among 30-49 year olds a significantly higher abortion rate and ratio was found for women from CES Asia and a significantly higher abortion ratio for women from CES Europe. 
Table 1 Abortion rate and abortion ratio for asylum seekers aged 15-49, comparing length of stay groups and with overall averages for the Netherlands ( $\mathrm{NL}$ )

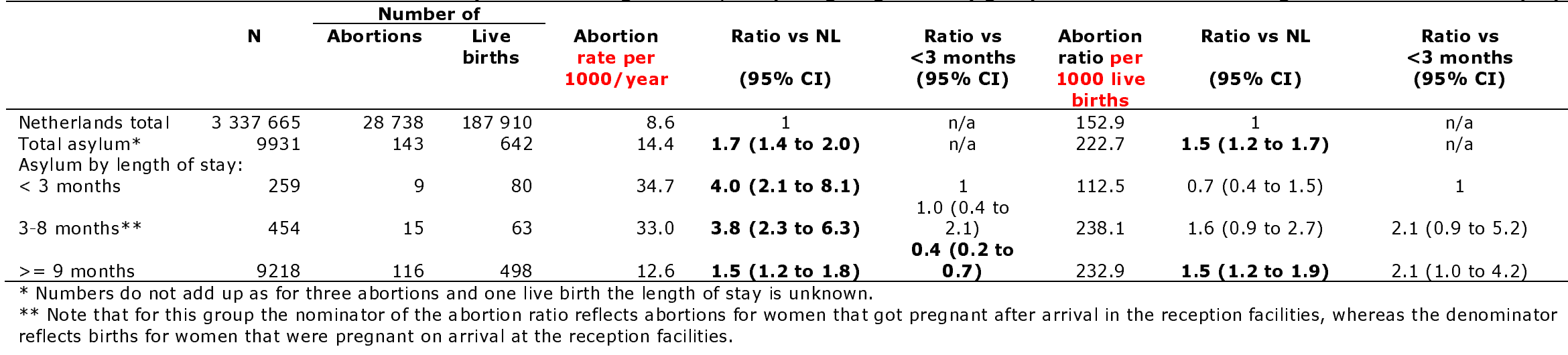

Table 2 Teenage birth rate for asylum seekers, comparing length of stay groups and with the average for the Netherlands (NL)

\begin{tabular}{|c|c|c|c|c|c|c|}
\hline & $\mathbf{N}$ & \multicolumn{2}{|c|}{ Number of } & Teenage birth rate & $\begin{array}{l}\text { Ratio vs NL } \\
(95 \% \mathrm{CI})\end{array}$ & $\begin{array}{c}\text { Ratio vs }<3 \text { months } \\
(95 \% \mathrm{CI})\end{array}$ \\
\hline Netherlands 15-19 & 479103 & 3713 & 2795 & 5.8 & 1 & $n / a$ \\
\hline Asylum 15-19* & 1650 & 39 & 81 & 49.1 & $8.4(6.8$ to 10.4$)$ & $\mathrm{n} / \mathrm{a}$ \\
\hline 3-8 months & 87 & 6 & 25 & 287.4 & 49.3 (35.3 to 68.7$)$ & $1.6(0.9$ to 2.9$)$ \\
\hline$>=9$ months & 1491 & 29 & 43 & 28.8 & $4.9(3.7$ to 6.7$)$ & $0.2(0.1$ to 0.3$)$ \\
\hline
\end{tabular}

* Numbers do not add up as for one abortion the length of stay is unknown. 


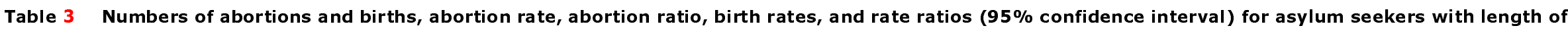
stay $>=9$ months in comparison with the Netherlands $(\mathrm{NL})$ by age group and region of origin*

\begin{tabular}{|c|c|c|c|c|c|c|c|c|c|}
\hline \multirow[b]{2}{*}{ Age group } & \multirow[b]{2}{*}{$\mathbf{N}$} & \multicolumn{2}{|c|}{ Number of } & \multirow[b]{2}{*}{$\begin{array}{l}\text { Abortion } \\
\text { rate per } \\
1000 / \text { year }\end{array}$} & \multirow[b]{2}{*}{$\begin{array}{c}\text { Ratio vs NL } \\
(95 \% \mathrm{CI})\end{array}$} & \multirow[b]{2}{*}{$\begin{array}{c}\text { Abortion } \\
\text { ratio per } \\
1000 \\
\text { live births }\end{array}$} & \multirow[b]{2}{*}{$\begin{array}{c}\text { Ratio vs NL } \\
(95 \% \mathrm{CI})\end{array}$} & \multirow[b]{2}{*}{$\begin{array}{c}\text { Teenage } \\
\text { birth rate } \\
\text { per } \\
1000 / \text { year }\end{array}$} & \multirow[b]{2}{*}{$\begin{array}{c}\text { Ratio vs NL } \\
\text { (95\% CI) }\end{array}$} \\
\hline & & Abortions & $\begin{array}{l}\text { Live } \\
\text { births }\end{array}$ & & & & & & \\
\hline \multicolumn{10}{|l|}{ Total 15-49 } \\
\hline Netherlands total & 3337665 & 28738 & 187910 & 8.6 & 1 & 152.9 & 1 & & \\
\hline \multirow{2}{*}{\multicolumn{10}{|c|}{ Of which**: }} \\
\hline & & & & & & & & & \\
\hline WCS Africa & 1744 & 42 & 174 & 24.1 & $2.8(2.1$ to 3.8$)$ & 241.4 & $1.6(1.1$ to 2.2$)$ & & \\
\hline NEH Africa & 906 & 10 & 63 & 11.0 & $1.3(0.7$ to 2.4$)$ & 158.7 & $1.0(0.5$ to 2.0$)$ & & \\
\hline CES Europe & 3060 & 30 & 98 & 9.8 & $1.1(0.8$ to 1.6$)$ & 306.1 & $2.0(1.3$ to 3.0$)$ & & \\
\hline M East/SW Asia & 2583 & 18 & 124 & 7.0 & $0.8(0.5-1.3)$ & 145.2 & $0.9(0.6$ to 1.6$)$ & & \\
\hline CES Asia & 555 & 12 & 24 & 21.6 & $2.5(1.4$ to 4.4$)$ & 500.0 & $3.3(1.6$ to 6.5$)$ & & \\
\hline \multicolumn{10}{|l|}{ 15-19 } \\
\hline Netherlands total & 479103 & 3713 & 2795 & 7.7 & 1 & 1328.4 & 1 & 5.8 & 1 \\
\hline Total asylum & 1491 & 29 & 43 & 19.5 & 2.5 (1.7 to 3.6$)$ & 674.4 & $0.5(0.3$ to 0.8$)$ & 28.8 & 4.9 (3.7 to 6.7$)$ \\
\hline \multicolumn{10}{|l|}{ Of which*: } \\
\hline WCS Africa & 321 & 14 & 29 & 43.6 & 5.6 (3.4 to 9.4$)$ & 482.8 & $0.4(0.2$ to 0.7$)$ & 90.3 & 15.5 (10.9 to 21.9 ) \\
\hline NEH Africa & 119 & 2 & 1 & 16.8 & $2.2(0.5$ to 8.6$)$ & 2000.0 & $1.5(0.1$ to 16.6$)$ & 8.4 & $1.4(0.2$ to 10.1$)$ \\
\hline CES Europe & 466 & 7 & 5 & 15.0 & $1.9(0.9$ to 4.0$)$ & 1400.0 & $1.1 \quad(0.3$ to 3.3$)$ & 10.7 & $1.8(0.8$ to 4.4$)$ \\
\hline M East/SW Asia & 412 & 2 & 2 & 4.9 & $0.6(0.2$ to 2.5$)$ & 1000.0 & $0.8(0.1$ to 5.3$)$ & 4.9 & $0.8(0.2$ to 3.3$)$ \\
\hline CES Asia & 107 & 4 & 5 & 37.4 & $4.8(1.8$ to 12.6$)$ & 800.0 & $1.2(0.3$ to 4.4$)$ & 46.7 & 8.0 (3.4 to 18.9$)$ \\
\hline \multicolumn{10}{|l|}{$20-29$} \\
\hline Netherlands total & 974218 & 12915 & 71498 & 13.3 & 1 & 180.6 & 1 & & \\
\hline Total asylum & 2919 & 41 & 253 & 14.0 & $1.1(0.8$ to 1.4$)$ & 162.1 & $0.9(0.6$ to 1.2$)$ & & \\
\hline \multicolumn{10}{|l|}{ Of which*: } \\
\hline WCS Africa & 841 & 22 & 94 & 26.2 & 2.0 (1.3 to 3.0$)$ & 234.0 & $1.3(0.8$ to 2.1$)$ & & \\
\hline NEH Africa & 345 & 5 & 39 & 14.5 & $1.1(0.5$ to 2.6$)$ & 128.2 & $0.7(0.3$ to 1.8$)$ & & \\
\hline CES Europe & 776 & 6 & 45 & 7.7 & $0.6(0.3$ to 1.3$)$ & 133.3 & $0.7(0.3$ to 1.7$)$ & & \\
\hline M East/SW Asia & 676 & 4 & 54 & 5.9 & $0.5(0.2$ to 1.2$)$ & 74.1 & $0.4(0.1$ to 1.1$)$ & & \\
\hline CES Asia & 170 & 3 & 12 & 17.6 & $1.3(0.4$ to 4.1$)$ & 250.0 & $1.4(0.4$ to 4.9$)$ & & \\
\hline \multicolumn{10}{|l|}{$30-49$} \\
\hline Netherlands total & 1884344 & 12110 & 113452 & 6.4 & 1 & 106.6 & 1 & & \\
\hline Total asylum & 4808 & 46 & 202 & 9.6 & $1.5(1.1$ to 2.0$)$ & 227.7 & 2.1 (1.6 to 2.9$)$ & & \\
\hline \multicolumn{10}{|l|}{ Of which*: } \\
\hline WCS Africa & 582 & 6 & 51 & 10.3 & $1.6(0.7$ to 3.6$)$ & 117.6 & $1.1(0.5$ to 2.6$)$ & & \\
\hline NEH Africa & 442 & 3 & 23 & 6.8 & $1.1(0.3$ to 3.3$)$ & 130.4 & $1.2(0.4$ to 4.1$)$ & & \\
\hline \multirow{4}{*}{$\begin{array}{l}\text { M East/SW Asia } \\
\text { CES Asia }\end{array}$} & 1818 & 17 & 48 & 9.4 & $1.5(0.9$ to 2.3$)$ & 354.2 & 3.3 (1.9 to 5.8$)$ & & \\
\hline & 1495 & 12 & 68 & 8.0 & $1.3(0.7$ to 2.2$)$ & 176.5 & $1.7(0.9$ to 3.1$)$ & & \\
\hline & & & & & & & 6.7 (2.1 to & & \\
\hline & 278 & 5 & 7 & 18.0 & $2.8(1.2$ to 6.7$)$ & 714.3 & 21.1) & & \\
\hline
\end{tabular}

* Region of origin explanation, per region the two most frequent countries are included. WCS Africa (West, Central, Southern Africa): Angola, Democratic Republic of Congo; NEH Africa (North, East, Horn of Africa): Somalia, Sudan; CES Europe (Central, East, Southern Europe): Azerbaijan, Former Yugoslavia; M East/SW Asia (Middle East and South West Asia): Afghanistan, Iraq; CES Asia (Central, East, Southern Asia): China, Sri Lanka (complete overview online).

** Numbers do not add up as the region code for some abortions is unknown. 


\section{Length of stay}

The abortion rate decreased considerably as the stay lengthened (table 4). This decrease was not explained by age or region of origin. The birth rate also decreased with length of stay (number of births per 1000 women per year, data not presented). We observed no clear pattern for the abortion ratio. The teenage birth rate was very high for girls with length of stay of between nine and twelve months and decreased in groups with longer stays.

Table 4 Number of abortions and live births, abortion rate, abortion ratio and teenage birth rate by length of stay in the reception facilities (length of stay $>=9$ months)

\begin{tabular}{|c|c|c|c|c|c|c|c|c|}
\hline $\begin{array}{l}\text { Length of stay in } \\
\text { reception facilities }\end{array}$ & $\begin{array}{c}N \\
15-49\end{array}$ & $\begin{array}{c}\text { Number of } \\
\text { abortions } \\
15-49\end{array}$ & $\begin{array}{l}\text { Number of } \\
\text { live births } \\
15-49\end{array}$ & $\begin{array}{c}\text { Abortion rate } \\
\text { per } 1000 \\
\text { aged } 15-49 \\
\text { /year* }\end{array}$ & $\begin{array}{c}\text { Abortion } \\
\text { Ratio } \\
15-49 * *\end{array}$ & $\begin{array}{c}N \\
15-19\end{array}$ & $\begin{array}{c}\text { Number of } \\
\text { teenage } \\
\text { births } \\
\text { /year }\end{array}$ & $\begin{array}{c}\text { Teenage birth } \\
\text { rate per } \\
1000 / \text { year } \\
* * *\end{array}$ \\
\hline 9 to 12 months & 174 & 5 & 34 & 28.7 & 147.1 & 35 & 7 & 200.0 \\
\hline 1 to 2 years & 921 & 19 & 70 & 20.6 & 271.4 & 228 & 11 & 48.2 \\
\hline 2 to 3 years & 852 & 15 & 60 & 17.6 & 250.0 & 168 & 11 & 65.5 \\
\hline 3 to 4 years & 1467 & 28 & 102 & 19.1 & 274.5 & 197 & 10 & 50.8 \\
\hline 4 to 5 years & 2133 & 24 & 104 & 11.3 & 230.8 & 303 & 3 & 9.9 \\
\hline 5 years or more & 3671 & 25 & 128 & 6.8 & 195.3 & 560 & 1 & 1.8 \\
\hline
\end{tabular}

Results of Poisson regression with the average value of length of stay intervals in the model as covariate:

* Dependent variable abortion rate, covariates length of stay and age: $z=-4.258, p<0.01$; controlling for region: $z=3.418, p<0.01$

** Dependent variable abortion ratio, covariate length of stay: not significant; covariates length of stay and age: not significant; covariates length of stay and region of origin: not significant.

*** Dependant variable teenage birth rate, covariate length of stay: $z=5.454, p<0.01$. 


\section{DISCUSSION}

The abortion rate and the teenage birth rate among asylum seekers were higher than average for the Netherlands. We found great differences between the subgroups by age, region of origin, and length of stay at the reception facilities. Looking at age group and region, 15-19 year olds from WCS Africa and CES Asia had the highest abortion and teenage birth rates. Pregnancies among 30-49 year olds from CES Asia, and to a lesser extent CES Europe, were aborted proportionally much more often than is seen on average in this age group in the Netherlands. Looking at the length of stay, the groups at highest risk of an abortion and of a teenage birth were asylum seekers with a length of stay less than three months and between three and eight months. Abortion and teenage birth rates decreased with increasing length of stay.

\section{Limitations}

The birth statistics are assumed to be complete, but some abortions may not have come to the knowledge of MOA staff or may not have been reported, causing an underestimate of the total number of abortions. This does not seem to affect our conclusions, however, as this underestimation is unlikely to be related to the variables analysed. The mid-study population data used are an accurate estimate of the person years spent at reception facilities: the number of women aged 15-49 on 1 April 2005 (9931) is similar to the average monthly population (9895). Comparison of the mid-year population for various groups by age and region of origin with monthly averages did not reveal great differences either. Indicators for unaccompanied minor asylum seekers (UMAs) could not be calculated due to incompleteness of the UMAstatus variable.

\section{Interpretation and comparison with results from other studies}

For the group with a length of stay less than three months the high abortion rate may relate to unwanted pregnancies conceived shortly before or during the flight. An unknown number of these women got pregnant because they were raped or forced to have sex with police, border guards or other people who took advantage of their vulnerability, had sex in exchange for safety or passage,[21] or simply had a 'normal' sex life during the long journey.[22] We assume that the low abortion ratio shortly after arrival is mainly a consequence of the fact that, for some women in this group, their pregnancy is in a stage where abortion is no longer an option. It may, however, also mean that women who recently arrived at the reception facilities were less aware of the availability of abortion services.

The high abortion rate for women with a length of stay of three to eight months implies a high incidence of unwanted pregnancies and therefore unprotected or insufficiently protected sex in the first few months after arrival at the reception facilities. Specific approaches and methods may need to be developed to increase effective prevention of unwanted pregnancies among newly arrived asylum seekers, especially teenagers, as for most of them their first concerns are the asylum procedure and practical issues in their new situation. To do so, more insight is required into why contraceptives are not used or used incorrectly, the needs of the women concerned, and what they think of the information and services provided.

The overall abortion rate for asylum seekers with a length of stay of nine months or more $(12.6 / 1000)$ is lower than the recent estimate by Sedgh et al for the entire world $(29 / 1000)$ and close to the estimate for 
Western Europe (12/1000).[14] The abortion ratio of 232.9 per 1000 live births is lower than the estimate for the world (310/1000) and at the same level as Western Europe (230/1000). The assumption that the reproductive health status of asylum seekers is poor is not reflected in the abortion indicators for female asylum seekers who have been at the reception facilities for a while. This may be a consequence of the fact that the Netherlands grants asylum seekers full access to reproductive health services.

The abortion rate and ratio are, as expected, associated with age, but the finding that the 15-19 age group had the highest abortion rate is striking, as the highest abortion rates are in general found in women in their 20s. [8, 13] An explanation may be that socioeconomic disadvantage, disrupted family structure, social isolation, and mental vulnerability, which are known to be risk factors for teenage pregnancy in the general population in Europe, [23, 24] affect a large proportion of teenage asylum seekers. In addition, young girls are assumed to be especially vulnerable to sexual abuse, and prostitution.[25] The high teenage birth rates may also be a consequence of the incorrect belief that women who give birth after arriving in the host country will be granted a residence permit. For UMAs, the desire to "have something of their own" may be a reason for the high birth rates.[26]

In line with the existence of worldwide variations in abortion indicators at a regional or subregional level,[14] we found considerable differences in abortion rates and ratios between asylum seekers from different regions of origin. But the pattern was not consistent across groups by age, region, or length of stay. Some subgroups of asylum seekers, especially those with longer lengths of stay, had lower abortion and teenage birth rates than women in the countries of origin. This is also seen among labour migrants in Europe and women in refugee camps in the regions of origin.[12] Whereas Eastern Europe is the region with the highest abortion rate and ratio worldwide,[14] the abortion rate we found among asylum seekers from this region was relatively low and the abortion ratio only high among 30-49 year olds. We found the highest abortion and teenage birth rates among teenage asylum seekers from WCS Africa and CES Asia. These are also the regions with the highest teenage birth rates in the world. [27] But although the teenage birth rate for girls in NEH Africa and M East/SW Asia is high, the abortion and birth rates for asylum seekers were relatively low. One explanation may be that childbearing among unmarried adolescents is more common in sub-Saharan Africa than in NEH Africa and M East/SW Asia.[27] The decrease of the abortion rate as the length of stay at reception facilities increased implies that asylum seekers benefit from the reproductive health education and services offered in the Netherlands. But the results in the Netherlands cannot automatically be extrapolated to other countries since only very few countries provide asylum seekers with full access to sexual and reproductive health services. $[7,9,28]$ It is worth investigating the reproductive health outcomes among asylum seekers in other countries.

\section{Conclusions}

Our study identified subgroups with high abortion and teenage birth rates: recently arrived women, especially young girls from WCS Africa and CES Asia, are at increased risk. More insight should be generated into why the rates in these groups are so high and good practices should be developed to address the reproductive health needs of these groups. The considerable overlap between asylum seeker populations in different host countries calls for international collaboration in this field. 
WHAT IS ALREADY KNOWN ON THIS SUBJECT

Little is known about the incidence of abortion and teenage births among asylum seekers in developed countries

WHAT THIS STUDY ADDS

The asylum population in the Netherlands had higher abortion rates than overall in the Netherlands due to subgroups at high risk

Women who were pregnant on arrival, women who got pregnant in the first few months after arrival, and teenagers and women aged 30-49 from specific regions were identified as risk groups

Abortion and teenage birth rates decreased as the length of stay at the reception facilities increased 
We thank the nurse practitioners from the Community Health Services for Asylum Seekers (MOA) who provided the study data and the Central Agency for the Reception of Asylum Seekers that provided the population data and the live birth data. We also thank Chris Schouten, Irene van Oostrum and Mirjanne Kessels (Community Health Services for Asylum Seekers) who commented on the manuscript.

Funding: Netherlands Association for Community Health Services.

Competing interests: All authors declare that the answers to the questions on the $B M J$ competing interest form (http://bmj.com/cgi/content/full/317/7154/291/DC1) are all No and therefore have nothing to declare.

Ethical approval: Not needed as only anonymous data were used that were collected by nurses in the light of regular health service provision. This is in line with medical ethical standards in the Netherlands and MOA's privacy statement.

The Corresponding Author has the right to grant on behalf of all authors and does grant on behalf of all authors, an exclusive licence (or non exclusive for government employees) on a worldwide basis to the BMJ Publishing Group Ltd and its Licensees to permit this article (if accepted) to be published in JECH editions and any other BMJPGL products to exploit all subsidiary rights, as set out in our licence (http://jech.bmj.com/ifora/licence.pdf). 


\section{REFERENCES}

1. Commission for Healthcare Audit and Inspection. Performing better? A focus on sexual health services in England. London: Commission for Healthcare Audit and Inspection, 2007.

2. Mayor S. Report calls for better data collection to improve sexual health in England. BMJ 2007;335:67.

3. EU Community Health Monitoring Programme. Reprostat: Reproductive health indicators in the European Union; final technical report. Lisbon: Instituto de Medicina Preventiva, 2003. http://ec.europa.eu/health/ph_projects/2001/monitoring/fp_monitoring 2001 a1_frep 02 en.pdf, accessed Feb 2008.

4. Bernstein S, Edouard L. Targeting access to reproductive health: giving contraception more prominence and using indicators to monitor progress. Reproductive health matters 2007;15(29):186191.

5. United Nations Population Fund. State of the world population 2006; a passage to hope, women and international migration. New York: UNFPA, 2006.

6. Carballo M, Katic B, Miller R, et al. Migration and reproductive health in Western Europe. Geneva: International Centre for Migration and Health, 2004.

7. Janssens K, Bosmans M, Leye E, et al. Sexual and reproductive health of asylum-seeking and refugee women in Europe: entitlements and access to health services. Journal of global ethics 2006;2(2):183196.

8. World Health Organization Regional Office for Europe. WHO regional strategy on sexual and reproductive health. Copenhagen: WHO, 2001.

9. Janssens $K$, Bosmans $M$, and Temmerman $M$. Sexual and reproductive health and rights of refugee women in Europe. Rights, policies, status and needs (literature review). Ghent: Academia Press, 2005.

10. United Nations High Commission for Refugees. State of the world's refugees 2006; human displacement in the new millennium. Geneva: UNHCR, 2006.

11. Save the Children. State of the world's mothers, 2003; protecting women and children in war and conflict. Westport: Save the Children, 2003.

12. McGinn T. Reproductive health of war-affected populations; what do we know. Int Fam Plan Perspect $2000 ; 26: 174-80$

13. Bankole A, Singh S, Haas T. Characteristics of women who obtain induced abortion: a worldwide review. International Family Planning Perspectives 1999;25(supplement):30-38.

14. Sedgh G, Henshaw SK, Singh S, et al. Induced abortion: estimated rates and trends worldwide. The Lancet 2007;370:1338-45.

15. Adams KM, Gardiner LD, Assefi N. Healthcare challenges from the developing world: post-immigration refugee medicine. BMJ 2004;328:1548-52.

16. Wijsen $C$, Lee $L$ van. National abortion registry (Landelijke abortus registratie 2005). Utrecht: Rutgers Nisso Goep, the Dutch Expert Centre on Sexuality, 2006.

17. Statistics Netherlands statline, http://statline.cbs.nl, accessed Feb 2008.

18. United Nations High Commissioner for Refugees. State of the world's refugees 2005. Geneva: UNCHR, 2005. http://www.unhcr.org. 
19. Rothman KJ, Greenland S. Modern Epidemiology. Philadelphia: Lippincott Williams and Wilkins, 1998.

20. Reynolds HT. The analysis of cross-classifications. New York, London: Free Press, Collier Macmillan, 1977.

21. United Nations High Commissioner for refugees. Sexual and gender-based violence against refugees, returnees and internally displaced persons; guidelines for prevention and response. Geneva: UNHCR, 2003. http://www.unhcr.org/publ/PUBL/3b9cc26c4.pdf, accessed Feb 2008.

22. Carling J. Migration, human smuggling and trafficking from Nigeria to Europe. Oslo: International peace research institute, 2007.

23. Imamura M, Tucker J, Hanaford $P$, et al. Reprostat 2: A systematic review of factors associated with teenage pregnancy in the European Union; final report. Aberdeen: University of Aberdeen, 2006. http://ec.europa.eu/health/ph_projects/2003/action1/docs/2003_1_27 frep_en.pdf, accessed Feb 2008.

24. Tripp J, Viner R. ABC of adolescence, sexual health, contraception, and teenage pregnancy. BMJ 2005; 330:590-3.

25. Brouns $M$, Burik A van, Kramer $S$, et al. The long wait for a safe future (Het lange wachten op een veilige toekomst). Rijswijk: Central Agency for the Reception of Asylum Seekers, 2003.

26. Wijsen C, Lee L van. Child of two worlds; a qualitative study into the backgrounds of teenage pregnancies in ethnic and cultural groups (Kind van twee werelden). Utrecht: Rutgers Nisso Groep, the Dutch Expert Centre on Sexuality, 2006.

27. World Health Organization. Adolescent pregnancy - unmet needs and undone deeds; a review of the literature and programmes. Geneva: WHO, 2007. http://whqlibdoc.who.int/publications/2004/9241591447 eng.pdf, accessed Feb 2008.

28. Bosmans $M$, Janssens $K$, Temmerman $M$. Sexual and reproductive health rights of asylum seeking and refugee women still neglected in the European Union. BZgA Forum 2006;2:16-19. 